\title{
Interleukin-15 Affects Patient Survival through Natural Killer Cell Recovery after Autologous Hematopoietic Stem Cell Transplantation for Non-Hodgkin Lymphomas
}

\author{
Luis F. Porrata, ${ }^{1}$ David J. Inwards, ${ }^{1}$ Ivana N. Micallef, ${ }^{1}$ Patrick B. Johnston, ${ }^{1}$ \\ Stephen M. Ansell, ${ }^{1}$ William J. Hogan, ${ }^{1}$ and Svetomir N. Markovic ${ }^{2}$ \\ ${ }^{1}$ Division of Hematology, Department of Medicine and Blood and Marrow Program, Mayo Clinic, 200 First Street SW, \\ Rochester, MN 55905, USA \\ ${ }^{2}$ Division of Hematology, Oncology Department, Mayo Clinic, 200 First Street SW, Rochester MN 55905, USA
}

Correspondence should be addressed to Luis F. Porrata, porrata.luis@mayo.edu

Received 3 June 2009; Revised 18 January 2010; Accepted 11 February 2010

Academic Editor: Mario Clerici

Copyright (C) 2010 Luis F. Porrata et al. This is an open access article distributed under the Creative Commons Attribution License, which permits unrestricted use, distribution, and reproduction in any medium, provided the original work is properly cited.

\begin{abstract}
Natural killer cells at day 15 (NK-15), after autologous peripheral blood hematopoietic stem cell transplantation (APHSCT), is a prognostic factor for overall survival (OS) and progression-free survival (PFS) in non-Hodgkin lymphoma (NHL). The potential role of the immunologic (homeostatic) environment affecting NK-15 recovery and survival post-APHSCT has not been fully studied. Therefore, we evaluate prospectively the cytokine profile in 50 NHL patients treated with APHSCT. Patients with an interleukin-15 (IL-15) $\geq 76.5 \mathrm{pg} / \mathrm{mL}$ at day 15 post-APHSCT experienced superior OS and PFS compared with those who did not; median OS; not reached versus 19.2 months, $P<.002$; and median PFS; not reached versus 6.8 months, $P<.002$, respectively. IL-15 was found to correlate with $\left(r_{s}=0.7, P<.0001\right)$ NK-15. Multivariate analysis showed only NK-15 as a prognostic factor for survival, suggesting that the survival benefit observed by IL-15 is most likely mediated by enhanced NK cell recovery post-APHSCT.
\end{abstract}

\section{Introduction}

Day 15 absolute lymphocyte count (ALC-15) after autologous peripheral blood hematopoietic stem cell transplantation (APHSCT) has been shown to be a significant predictor for survival in multiple hematologic malignancies [1-9] as well as solid tumors [10-12]. Natural killer cells at day 15 (NK-15) have been identified as the key lymphocyte subset in the ALC-15 that has a direct impact on survival postAPHSCT [13]. In addition, the lymphocytes collected at the same time with stem cells and infused to the patients have a direct impact on ALC-15 and NK-15 post-APHSCT, suggesting that the autograft can be viewed not only as the means to achieve hematologic engraftment by the infusion of stem cells but also as an adoptive immunotherapeutic maneuver by infusion of an autograft absolute lymphocyte count (A-ALC) affecting immune recovery and survival postAPHSCT [14-16]. Adoptive cellular therapy depends on the ability to optimally select the desired antigenic specificity immune effector cells and then induce cellular proliferation while preserving the effector function, engraftment, and homing abilities of the lymphocytes [17]. The infusion of A-ALC will provide the desired antigenic immune effector cells, but what factors to induce cellular proliferation while preserving the effector function, engraftment and homing abilities of the lymphocytes to provide an effective adoptive cellular therapy in APHSCT are currently not well defined. Therefore, we set out to investigate the cytokine milieu at day 15 post-APHSCT to assess which cytokines affect NK-15 and the superior survival mediated by a faster NK-15 recovery post-APHSCT. To achieve this goal the following endpoints were evaluated in the study: (1) to assess a correlation between cytokines and NK-15 post-APHSCT, (2) to assess if interleukin-15 (IL-15) affects survival post-APHSCT and through which immune effector cell, and (3) to identify a source of IL-15 production at day 15 post-APHSCT. 


\section{Material and Methods}

2.1. Patient Population. Patients in the study were the same patient group enrolled in prospective study from February 2002 to February 2007 to assess the role of ALC-15 and NK15 on survival post-APHSCT [13]. For this study 27 normal controls donated blood samples to assess cytokines levels. All patients signed written, informed consent to participate in the study. Approval of the study was obtained from the Mayo Clinic institutional review board and was in accordance with U.S. federal regulations and the Declaration of Helsinki.

2.2. A-ALC, ALC-15, Monocytes, and NK-15. Autograft absolute lymphocyte count (A-ALC) was determined as previously reported: \% collection lymphocytes $\times$ absolute autograft white blood cell count/kilogram (kg) [18]. Autograft monocyte count (A-mono) was determined as follows: $\%$ collection monocytes $\times$ absolute autograft white blood cell count $/ \mathrm{kg}$. ALC-15 and monocytes at day 15 (mono15) were determined from the differential white blood cell count obtained at day 15 post-APHSCT. NK-15, defined as $\mathrm{CD}^{2} 6^{+} / \mathrm{CD}^{2} 6^{+} / \mathrm{CD}^{-}$, was according to manufacture's recommendations. Stained cells were then analyzed using flow cytometry (FACS callibur, Becton-Dickson, CA). Cells were analyzed for the percentage of cells expressing said antigens as well as average quantity of antigen expression [13].

2.3. Cytokine Assay. Cytokines were measured using the Bio-rad (Hercules, CA) human 27-plex system. Briefly, diluted human plasma was incubated for $30^{\prime}$ at room temperature with washed beads. The beads are coated with antibodies to the cytokines of interest. After incubation with patient plasma the beads were washed and incubated for $30^{\prime}$ with biotinylated 20 antibodies, followed by incubation with PE-conjugated streptavidin. Quantization of cytokines was performed on the Luminex 200 system (Austin, TX). The cytokines tested included Interleukin (IL)1b, IL-1ra, IL-2, IL-4, IL-5, IL-6, IL-7, IL-8, IL-9, IL-10, IL-12p70, IL-13, IL-15, IL-17, Eotaxin, fibroblast growth factor (FGF), granulocyte colony-stimulating factor (G$\mathrm{CSF}$ ), granulocyte-macrophage colony-stimulating factor (GM-CSF), interferon-gamma (IFN-G), interferon-gammainducible protein 10 (IP-10), monocyte chemoattractant protein-1 (MCP-1), macrophage inflammatory proteins 1a and $1 \mathrm{~b}$ (MIP-1a and MIP-1b), platelet-derived growth factor (PDGF), RANTES, tumor-necrosis-factor-gamma (TNF-G), and vascular endothelial growth factor (VEGF).

2.4. Prognostic Factors. Prognostic factors for post-APHSCT OS and PFS evaluated in this study included cytokines, ALC15 , NK-15, mono-15, international prognostic index (IPI) factors, infused CD34, and disease status at transplant.

2.5. Peripheral Blood Stem Cell Collection. All patients received G-CSF ( $10 \mu \mathrm{g} / \mathrm{kg})$ daily for 5 to 7 consecutive days by subcutaneous injection. Once their peripheral blood CD $34^{+}$ cell count was $\geq 10$ cells $/ \mu \mathrm{L}$, patients began daily apheresis until they achieved a target of $5 \times 10^{6} \mathrm{CD} 34^{+}$cells $/ \mathrm{kg}$. A minimum target of $2 \times 10^{6} \mathrm{CD} 34^{+}$cells $/ \mathrm{kg}$ was required for the patient to be considered for transplantation. Patients were assigned to the Baxter Amicus (Baxter, healthcare Corp., Deerfield, IL), Fenwal CS 3000 Plus (Baxter) or COBE Spectra (Gambro BCT, Lakewood, CO) based on instrument availability on the day of collection. Instrument setting used for the collection procedures has previously been described (ref). The number of apheresis collections was dependent upon collection of an adequate number of $\mathrm{CD} 34^{+}$cells to achieve hematologic engraftment post-APHSCT.

2.6. Conditioning Regimen. All patients received Carmustine (BCNU) $300 \mathrm{mg} / \mathrm{m}^{2}$ on day-6; etoposide $100 \mathrm{mg} \cdot \mathrm{m}^{2}$ twice a day on days-5, -4, -3, and -2 ; and melphalan $140 \mathrm{mg} / \mathrm{m}^{2}$ on day-1 (BEAM). All patients received growth factor support starting on day +6 with sargramostim $500 \mu \mathrm{g}$ daily until evidence of neutrophilic engraftment defined as an absolute neutrophil count $(\mathrm{ANC}) \geq 500$ cells $/ \mu \mathrm{g}$ on 3 consecutive days.

2.7. Response and Survival. Response criteria were based on the guidelines from the non-Hodgkin lymphoma (NHL) international Workshop [19]. OS was measured from the date of transplant to the date of death, or last follow-up. PFS was defined as the time from transplant to the time of progression, relapse, death, or last follow-up.

2.8. Statistical Analysis. OS and PFS were analyzed using the approach of Kaplan and Meier [20]. Differences between survival curves were tested for statistical significance using the 2-tailed log-rank test. The Cox proportional hazard model [21] was used for the univariate and multivariate analysis to evaluate cytokines, NK-15, ALC-15, and mono-15 as a prognostic factor for post-APHSCT OS and PFS times.

In addition to the evaluation of cytokines (specifically IL-15) and its prognostic significance for OS and PFS, its utility as a marker of NK-15 was also assessed. The choice of optimal cutoff of IL-15 was based on its utility as a marker of NK-15 using Receiver operating characteristics (ROCs) curves and area under the curve (AUC) as well as its prognostic value for post-APHSCT OS and PFS. Prediction of NK-15 was explored further in logistic regression models, univariately assessing continuous and dichotomized values of A-ALC, cytokines, and mono-15. $\chi^{2}$-tests were used to determine relationships between categorical variables. The Wilcoxon-rank test was used to determine associations between continuous variable and categories, and Spearman correlation coefficients were used to evaluate associations for continuous variables. Owing to multiple factors tested in the univariate analysis, multiple comparison corrections using Bonferroni correction procedure were applied declaring statistical significance at $P<.002(\alpha=0.05 / n, n=27$ cytokines).

The cut-off of ALC- $15 \geq 500$ cells $/ \mu$ L, A-ALC $\geq 0.5 \times 10^{9}$ lymphocytes $/ \mathrm{kg}$, and NK-15 $\geq 80$ cells $/ \mu \mathrm{L}$ was based on data from our previous studies [13-15]. 
TABLE 1: Baseline characteristics of the cohort.

\begin{tabular}{|c|c|c|c|}
\hline Characteristics & $n(\%)$ & Median & Range \\
\hline Age at transplant, years & $50(100 \%)$ & 57.5 & $(23-73)$ \\
\hline \multicolumn{4}{|l|}{ Sex } \\
\hline Female & $17(34 \%)$ & & \\
\hline Male & $33(66 \%)$ & & \\
\hline \multicolumn{4}{|l|}{ Lymphoma type } \\
\hline DLBCL & $34(68 \%)$ & & \\
\hline Mantle cell & $10(20 \%)$ & & \\
\hline T-cell & $5(10 \%)$ & & \\
\hline Follicular & $1(2 \%)$ & & \\
\hline \multicolumn{4}{|l|}{ Prognostic factors at diagnosis } \\
\hline \multicolumn{4}{|l|}{ Extra nodal sites } \\
\hline 0 & $33(66 \%)$ & & \\
\hline 1 & $15(30 \%)$ & & \\
\hline 2 & $2(4 \%)$ & & \\
\hline LDH (U/L) & $50(100 \%)$ & 209 & $(150-1515)$ \\
\hline \multicolumn{4}{|l|}{ Performance status } \\
\hline 0 & $31(62 \%)$ & & \\
\hline 1 & $17(34 \%)$ & & \\
\hline 2 & $2(4 \%)$ & & \\
\hline \multicolumn{4}{|l|}{ Stage } \\
\hline I & $6(12 \%)$ & & \\
\hline II & $5(10 \%)$ & & \\
\hline III & $8(16 \%)$ & & \\
\hline IV & $31(62 \%)$ & & \\
\hline \multicolumn{4}{|l|}{ IPI score } \\
\hline \multicolumn{4}{|l|}{ Age at transplant, years } \\
\hline$\geq 60$ & $23(46 \%)$ & & \\
\hline$<60$ & $27(56 \%)$ & & \\
\hline \multicolumn{4}{|l|}{$\mathrm{LDH}$} \\
\hline Normal & $21(42 \%)$ & & \\
\hline Abnormal & $29(58 \%)$ & & \\
\hline \multicolumn{4}{|l|}{ Extra nodal sites } \\
\hline$\geq 2$ & $2(4 \%)$ & & \\
\hline$<2$ & $48(96 \%)$ & & \\
\hline \multicolumn{4}{|l|}{ Performance status } \\
\hline$\geq 2$ & $2(4 \%)$ & & \\
\hline$<2$ & $48(96 \%)$ & & \\
\hline \multicolumn{4}{|l|}{ Stage } \\
\hline I/II & $11(22 \%)$ & & \\
\hline III/IV & $39(78 \%)$ & & \\
\hline Infused CD34 cells $\times 10^{6} / \mathrm{kg}$ & $50(100 \%)$ & 4.68 & $(2.03-8.56)$ \\
\hline Infused A-ALC $\times 10^{9}$ lymphocytes $/ \mathrm{kg}$ & $50(100 \%)$ & 0.55 & $(0.08-1.5)$ \\
\hline ALC- 15 cells $/ \mu \mathrm{L}$ & $50(100 \%)$ & 670 & $(2.0-4,500)$ \\
\hline NK-15 cells $/ \mu \mathrm{L}$ & $50(100 \%)$ & 103 & $(10-999)$ \\
\hline Mono- 15 cells $/ \mu \mathrm{L}$ & $50(100 \%)$ & 860 & $(2.0-4,500)$ \\
\hline Infused A-mono $\times 10^{9}$ monocytes $/ \mathrm{kg}$ & $50(100 \%)$ & 0.58 & $(0.08-1.5)$ \\
\hline
\end{tabular}

A-ALC: autograft, absolute lymphocyte count; ALC-15: absolute lymphocyte count at day 15 post transplant; A-mono: autograft absolute monocyte count; DLBCL: diffuse large B-cell lymphoma; IPI: International prognostic index; LDH: lactate dehydrogenase; Mono-15: absolute monocyte count at day 15 post transplant; NK-15: absolute natural killer cell count at day 15 post transplant. 
TABLE 2: Cytokines levels comparison between normal volunteers, before transplantation, and at day 15 after transplantation.

\begin{tabular}{|c|c|c|c|c|c|c|}
\hline Cytokines & Normal & Pretransplant & $\begin{array}{l}\text { Day } 15 \text { post } \\
\text { transplant }\end{array}$ & $\begin{array}{c}P \text {-value Normal } \\
\text { versus } \\
\text { Pretransplant }\end{array}$ & $\begin{array}{c}P \text {-value Normal } \\
\text { versus Day } 15 \\
\text { post transplant }\end{array}$ & $\begin{array}{c}P \text {-value Pre } \\
\text { versus Day } \\
15 \text { post } \\
\text { transplant }\end{array}$ \\
\hline & $\begin{array}{l}\text { Median } \\
\text { (25th-75th } \\
\text { quartiles) }\end{array}$ & $\begin{array}{l}\text { Median } \\
\text { (25th-75th } \\
\text { quartiles) }\end{array}$ & $\begin{array}{l}\text { Median } \\
\text { (25th-75th } \\
\text { quartiles) }\end{array}$ & & & \\
\hline IL-1b & $3.59(2.32-5.55)$ & $4.72(3.48-7.79)$ & $2.99(1.3-8.11)$ & .5 & .8 & .1 \\
\hline IL-1ra & $\begin{array}{c}120.12 \\
(90.59-287.77)\end{array}$ & $\begin{array}{c}356.56 \\
(228.95-662.87)\end{array}$ & $\begin{array}{c}283.33 \\
(142.52-434.73)\end{array}$ & $<.0001$ & $<.0001$ & .01 \\
\hline IL-2 & $0(0-56.12)$ & $4.24(0-23.87)$ & $0(0-7.89)$ & .01 & .7 & $<.0004$ \\
\hline IL-4 & 3.09 (2.09-3.99) & $3.95(3.33-5.43)$ & $2.12(1.25-3.63)$ & .6 & .7 & .02 \\
\hline IL-5 & $0.92(0.69-1.67)$ & $2.82(1.79-3.96)$ & $4.3(2.93-13.75)$ & $<.0001$ & $<.0001$ & .01 \\
\hline IL-6 & $0(0-2.14)$ & $11.78(5.6-21.05)$ & $\begin{array}{c}24.48 \\
(9.84-48.72)\end{array}$ & $<.0001$ & $<.0001$ & .01 \\
\hline IL-7 & $\begin{array}{c}24.64 \\
(13.59-39.08)\end{array}$ & $\begin{array}{c}21.99 \\
(16.85-39.95)\end{array}$ & $\begin{array}{c}15.66 \\
(5.77-26.61)\end{array}$ & .04 & .007 & .02 \\
\hline IL-8 & $2.57(0.35-7.71)$ & $\begin{array}{c}30.89 \\
(19.91-97.72)\end{array}$ & $\begin{array}{c}36.67 \\
(27.02-71.78)\end{array}$ & $<.0001$ & $<.0001$ & .2 \\
\hline IL-9 & $4.09(0-68.28)$ & $\begin{array}{c}40.18 \\
(4.93-91.22)\end{array}$ & $27.58(8.29-64)$ & .04 & .04 & .003 \\
\hline IL-10 & $1.97(1.24-3.84)$ & $4.91(3.91-8.16)$ & $8.94(5.91-13.61)$ & .01 & $<.0001$ & $<.002$ \\
\hline IL-12p70 & $6.7(2.52-16.35)$ & $\begin{array}{c}15.27 \\
(7.29-29.68)\end{array}$ & $7.61(4.45-12.93)$ & $<.0006$ & .2 & $<.0004$ \\
\hline IL-13 & $2.93(1.33-4.17)$ & $2.49(1.71-5.26)$ & $1.46(0.56-2.31)$ & .02 & .5 & $<.002$ \\
\hline IL-15 & $0(0-0)$ & $8.75(0.07-110.5)$ & $76.5(5.4-219.22)$ & $<.0001$ & $<.0001$ & $<.0001$ \\
\hline IL-17 & $10.62(0-30.66)$ & $\begin{array}{c}18.43 \\
(4.33-49.92)\end{array}$ & $7.08(0-17.14)$ & .01 & .2 & $<.0001$ \\
\hline Eotaxin & $\begin{array}{c}49.39 \\
(41.43-76.41)\end{array}$ & $\begin{array}{c}68.18 \\
(42.26-104.04)\end{array}$ & $\begin{array}{c}73.76 \\
(44.96-108.87)\end{array}$ & .02 & $<.0001$ & .6 \\
\hline FGF & $0(0-0)$ & $0(0-84.64)$ & $0(0-13.07)$ & .7 & .8 & .7 \\
\hline G-CSF & $989(385-1243)$ & $\begin{array}{c}83.08 \\
(60.01-124.8)\end{array}$ & $\begin{array}{c}67.48 \\
(45.74-93.55)\end{array}$ & $<.0001$ & $<.0001$ & $<.0001$ \\
\hline GM-CSF & $\begin{array}{c}161.74 \\
(32.26-1142.8)\end{array}$ & $\begin{array}{c}80.99 \\
(41.13-173.59)\end{array}$ & $\begin{array}{c}63.75 \\
(25.4-164.6)\end{array}$ & .01 & $<.0001$ & $<.002$ \\
\hline IFN-G & $\begin{array}{c}142.49 \\
(87.71-264.05)\end{array}$ & $\begin{array}{c}125.06 \\
(78.04-193.52)\end{array}$ & $\begin{array}{c}65.65 \\
(28.81-86.42)\end{array}$ & .03 & $<.0009$ & $<.0001$ \\
\hline IP-10 & $\begin{array}{c}245.22 \\
(150.9-326.4)\end{array}$ & $\begin{array}{c}915.6 \\
(585.98-1783.83)\end{array}$ & $\begin{array}{c}1440.53 \\
(102.2-3067.40)\end{array}$ & $<.0001$ & $<.0001$ & $<.0001$ \\
\hline MCP-1 & $41.3(0-90.25)$ & $\begin{array}{c}86.34 \\
(33.83-146.48)\end{array}$ & $\begin{array}{c}120.43 \\
(54.46-209.55)\end{array}$ & .02 & $<.0001$ & .008 \\
\hline MIP-1a & $7.4(4.58-10.52)$ & $12.9(8.62-31.7)$ & $8.56(5.35-1363)$ & $<.001$ & .7 & $<.001$ \\
\hline MIP-1b & $\begin{array}{c}51.23 \\
(21.15-106.98)\end{array}$ & $\begin{array}{c}97.36 \\
(57.01-256.38)\end{array}$ & $\begin{array}{c}104.34 \\
(63.59-179.76)\end{array}$ & $<.002$ & $<.0001$ & .6 \\
\hline PDGF & $\begin{array}{c}1260.24 \\
(805.22-2289.82)\end{array}$ & $\begin{array}{c}2071.16 \\
(1060.34- \\
3485.72)\end{array}$ & $\begin{array}{c}423.71 \\
(112.94-697.84)\end{array}$ & $<.0001$ & $<.0001$ & $<.0001$ \\
\hline RANTES & $\begin{array}{c}2650.98 \\
(1584.55-4500)\end{array}$ & $2600(2600-3000)$ & $\begin{array}{c}2302.37 \\
(297.92-1072.83)\end{array}$ & .7 & .1 & $<.001$ \\
\hline TNF-G & $0.74(0-188.99)$ & $\begin{array}{c}70.48 \\
(52.82-132.48)\end{array}$ & $\begin{array}{c}32.06 \\
(23.37-82.85)\end{array}$ & .02 & .07 & $<.0001$ \\
\hline VEGF & $23.13(12-55.42)$ & $\begin{array}{c}77.38 \\
(28.42-104.34)\end{array}$ & $\begin{array}{c}36.52 \\
(10.28-91.85)\end{array}$ & $<.0007$ & $<.002$ & $<.0001$ \\
\hline
\end{tabular}

Interleukin (IL)-1b, IL-1ra, IL-2, IL-4, IL-5, IL-6, IL-7, IL-8, IL-9, IL-10, IL-12p70, IL-13, IL-15, IL-17, Eotaxin, fibroblast growth factor (FGF), granulocyte colony-stimulating factor (G-CSF), granulocyte-macrophage colony-stimulating factor (GM-CSF), interferon-gamma (IFN-G), interferon-gamma-inducible protein 10 (IP-10), monocyte chemoattractant protein-1 (MCP-1), macrophage inflammatory proteins 1a and 1b (MIP-1a and MIP-1b), platelet-derived growth factor (PDGF), RANTES, tumor-necrosis-factor-gamma (TNF-G), and vascular endothelial growth factor (VEGF). 


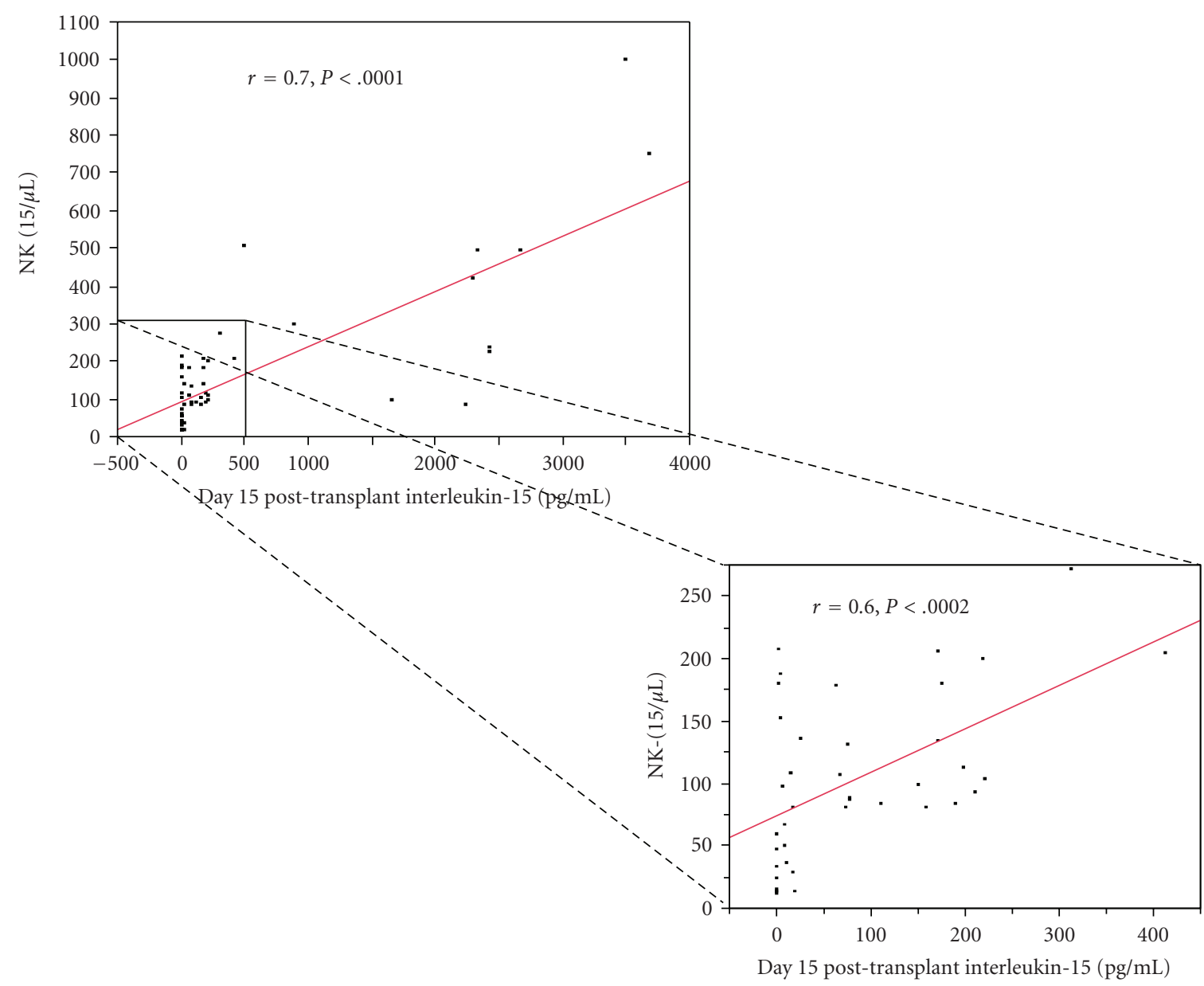

FIGURE 1: Scatterplot comparing IL-15 and NK-15 at day 15 post-APHSCT. Strong positive correlation was identified between IL-15 and NK-15 post-APHSCT (Spearman correlation rho factor, $r_{s}=0.7, P<.0001$ ). Only 11 patients had IL- 15 level higher than $500 \mathrm{pg} / \mathrm{mL}$. To rule out the possibility that these 11 patients made skewed the data resulting in the strong correlation between IL-15 and NK-15, we truncated and analyzed the data for the 39 patients that had IL-15 levels between 0 and $500 \mathrm{pg} / \mathrm{mL}$. A strong positive correlation was still observed between IL-15 and NK-15 (Spearman correlation rho factor, $r_{s}=0.6, P<.0002$ ).

\section{Results}

3.1. Patient Characteristics. The median age at the time of transplant for this cohort of 50 NHL patients was 57.7 years (range: 23-73). Baseline characteristics for the patients are described on Table 1. No patients were lost to follow-up. The updated median follow-up for the cohort was 25.2 months (range: 6-80.8 months). By the time of this analysis 25 patients $(50 \%)$ had evidence of relapse and 18 patients $(36 \%)$ had died. The transplant-related mortality for the cohort was only $2 \%$ ( 1 of 50 ). One patient died of an intracranial bleed, the rest because of progressive lymphoma. No patient received fludarabine-based regimens prior to APHSCT.

Table 2 shows the cytokine levels comparison between normal volunteers and the cohort of patients before APHSCT and at day 15 post-APHSCT. The following cytokines showed increased levels at day 15 post-APHSCT compared with normal volunteers and before APHSCT: IL-5, IL-6, IL8, IL-10, IL-15, IP-10, MCP-1, and MIP-1b. No sargramostim was administered on day 15 post-APHSCT during research blood collection for the study as all patients engrafted their neutrophils prior to day 15 post-APHSCT.

3.2. IL-15 and NK-15. We previously reported that NK-15 is the key lymphocyte subset at day 15 affecting survival post-APHSCT. Thus we set out to investigate which cytokine affects NK-15 recovery post-APHSCT. Table 3 shows the cytokine univariate analysis for correlation with NK-15. IL-15 and fibroblast growth factor (FGF) were strongly correlated with NK-15. We also published that A-ALC affected NK-15 recovery. In logistic regression analysis, both A-ALC $(P<.001)$ and IL-15 $(P<.002)$ retained their ability to affect NK-15 recovery post-APHSCT. IL-15 was found to be both a strong predictor for area under the curve (AUC = $0.87, P<.002)$ and strongly correlated with $\left(r_{s}=0.7\right.$, $P<.0001)$ NK-15. Figure 1 shows the scatter plot for IL15 and NK-15. Only 11 patients had IL-15 level higher than $500 \mathrm{pg} / \mathrm{mL}$. To rule out the possibility that these 11 patients made skewed the data resulting in the strong correlation 
TABLE 3: Univariate analysis of the correlation between cytokines and NK-15.

\begin{tabular}{|c|c|c|}
\hline Cytokines & Spearman (rho) correlation & $P$-value \\
\hline IL-1b & 0.17 & .2 \\
\hline IL-1ra & 0.09 & .5 \\
\hline IL-2 & 0.06 & .7 \\
\hline IL-4 & 0.2 & .1 \\
\hline IL-5 & 0.2 & .2 \\
\hline IL-6 & 0.1 & .3 \\
\hline IL-7 & 0.06 & .6 \\
\hline IL-8 & 0.2 & .1 \\
\hline IL-9 & 0.2 & .1 \\
\hline IL-10 & -0.2 & .3 \\
\hline IL-12p70 & 0.1 & .4 \\
\hline IL-13 & 0.1 & .5 \\
\hline IL-15 & 0.7 & $<.0001$ \\
\hline IL-17 & 0.1 & .4 \\
\hline Eotaxin & 0.1 & .3 \\
\hline FGF & 0.6 & $<.0001$ \\
\hline G-GSF & 0.1 & .3 \\
\hline GM-CSF & 0.1 & .4 \\
\hline IFN-G & 0.2 & .2 \\
\hline IP-10 & 0.1 & .4 \\
\hline MCP-1 & 0.06 & .7 \\
\hline MIP-1a & 0.2 & .2 \\
\hline MIP-1b & 0.2 & .2 \\
\hline PDGF & 0.2 & .1 \\
\hline RANTES & 0.06 & .7 \\
\hline TNF- $\alpha$ & 0.3 & .06 \\
\hline VEGF & 0.2 & .2 \\
\hline
\end{tabular}

Interleukin (IL)-1b, IL-1 ra, IL-2, IL-4, IL-5, IL-6, IL-7, IL-8, IL-9, IL-10, IL12p70, IL-13, IL-15, IL-17, Eotaxin, fibroblast growth factor (FGF), granulocyte colony-stimulating factor (G-CSF), granulocyte-macrophage colonystimulating factor (GM-CSF), interferon-gamma (IFN-G), interferongamma-inducible protein 10 (IP-10), monocyte chemoattractant protein1 (MCP-1), macrophage inflammatory proteins $1 \mathrm{a}$ and $1 \mathrm{~b}$ (MIP-1a and MIP-1b), platelet-derived growth factor (PDGF), RANTES, tumor-necrosisfactor-gamma (TNF-G), and vascular endothelial growth factor (VEGF).

between IL-15 and NK-15, we truncated and analyzed the data for the 39 patients that had IL-15 levels between 0 and $500 \mathrm{pg} / \mathrm{mL}$. We still observed a strong correlation between IL15 and NK-15 $\left(r_{s}=0.6, P<.0002\right)$. If we dichotomized the NK-15, patients with an NK-15 $\geq 80$ cells/ $\mu \mathrm{L}$ had higher levels of IL-15 compared with those who did not (median IL-15 of $155 \mathrm{pg} / \mathrm{mL}$ versus $8.89 \mathrm{pg} / \mathrm{mL}, P<.002$ ) (Figure 2 ).

3.3. Cytokines and Survival Post-APHSCT. Table 4 shows the cytokines univariate analysis for survival post-APHSCT. The cytokines were evaluated as continuous variables. IL-15 at day 15 post-APHSCT was the only cytokine that was statistically significant for OS. IL-15 and PDGF were statistically significant for PFS. In the multivariate analysis for PFS, IL-15 was the only cytokine that remained statistically significant $(\mathrm{IL}-15: \mathrm{HR}=0.950 ; 95 \% \mathrm{CI}=0.824-0.978, P<.002$; PDGF: $\mathrm{HR}=1.020 ; 95 \% \mathrm{CI}=1.010-1.058, P=.02)$.

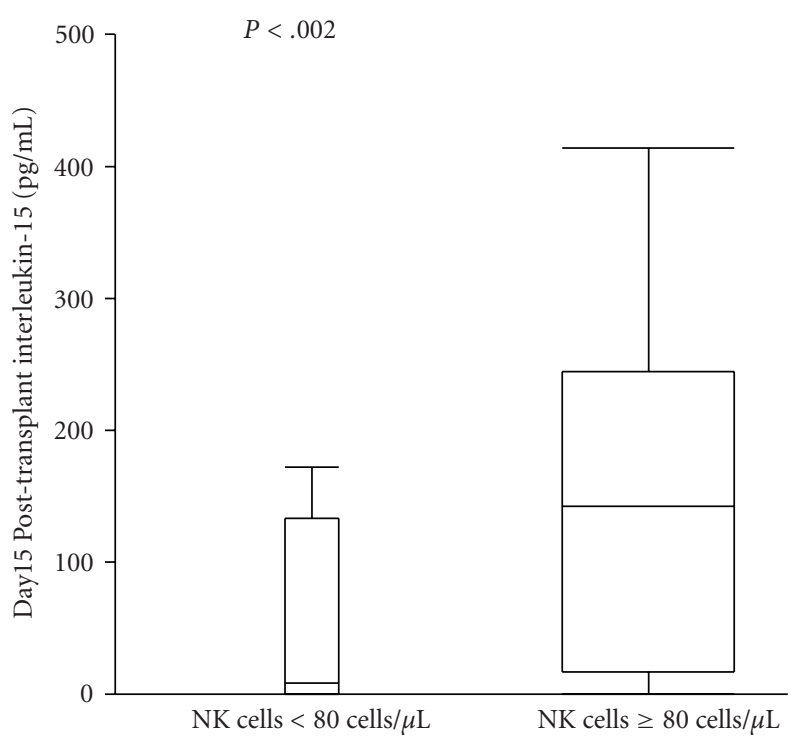

Figure 2: Box plot comparing the IL-15 levels at day 15 postAPHSCT between patients with an NK-15 $\geq 80$ cells/ $\mu \mathrm{L}$ and NK$15<80$ cells/ $\mu \mathrm{L}$. Patients with a NK-15 $\geq 80$ cells $/ \mu \mathrm{L}$ had a higher IL-15 levels (median of $155 \mathrm{pg} / \mathrm{mL}$ ) compared with patients with aNK-15 $<80$ cells $/ \mu \mathrm{L}$ (median of $8.89 \mathrm{pg} / \mathrm{mL})(P<.002)$ at day 15 post-APHSCT.

A cut-off of $76.5 \mathrm{pg} / \mathrm{mL}$ for IL-15 was supported by being the median value of the data as well as it yielded the greatest differential in survival based on $\chi^{2}$ values analyzed at different cutoff points (between the 25th and 75th quartiles) from the log-rank tests. Patients with an IL-15 $\geq 76.5 \mathrm{pg} / \mathrm{mL}$ $(n=25)$ experienced superior OS (Figure 3(a)) and PFS (Figure 3(b)) compared with those who did not $(n=25)$; median OS; not reached versus 19.2 months, 3 years OS rates of $79 \%$ versus $47 \%, P<.002$; and median PFS; not reached versus 6.8 months, 3 years PFS rates of $64 \%$ versus $31 \%$, $P<.002$, respectively.

In order to minimize uncontrolled factors that could have affected IL-15 levels post-APHSCT, we analyzed patients characteristics based on IL- $15 \geq 76.5 \mathrm{pg} / \mathrm{mL}$ versus an IL$15<76.5 \mathrm{pg} / \mathrm{mL}$ (Table 5). We also analyzed if the pretransplant IL-15 levels were associated with day 15 postAPHSCT IL-15 levels. We found a positive correlation between pre- and post-APHSCT IL-15 levels $(r=0.6, P<$ .0001).

To assess the role on survival of NK-15 and IL-15, we categorized the patients into 4 groups: group I was patients with an NK-15 $\geq 80$ cells $/ \mu \mathrm{L}$ and IL- $15 \geq 76.5 \mathrm{pg} / \mathrm{mL}$; group II was NK-15 $\geq 80$ cells $/ \mu \mathrm{L}$ and IL- $15<76.5 \mathrm{pg} / \mathrm{mL}$; group III was NK-15 $<80$ cells $/ \mu \mathrm{L}$ and IL- $15 \geq 76.5 \mathrm{pg} / \mathrm{mL}$; group IV was NK-15 $<80$ cells $/ \mu \mathrm{L}$ and IL- $15<76.5 \mathrm{pg} / \mathrm{mL}$. We observed worsening PFS in patients with progressing low NK-15 and IL-15 levels compared with patients with high NK-15 and IL-15 levels (3 years PFS rates for group I was $68 \%$; group II was 49\%; group III was 33\%; group IV was $0 \%$ ) (Figure 4). In the multivariate analysis comparing NK15 and IL-15 for OS and PFS, NK-15 truncated IL-15 (OS; $\mathrm{HR}=0.32, P=.02$; and PFS: $\mathrm{HR}=0.33, P=.01)$. 
TABLE 4: Univariate analysis for overall and progression-free survival.

\begin{tabular}{|c|c|c|}
\hline Cytokines & Overall survival $P$-value & Progression-free survival $P$-value \\
\hline IL-1b & .08 & .1 \\
\hline IL-1ra & .2 & .4 \\
\hline IL-2 & .09 & .1 \\
\hline IL-4 & .03 & .02 \\
\hline IL-5 & .8 & .3 \\
\hline IL-6 & .07 & .08 \\
\hline IL-7 & .06 & .06 \\
\hline IL-8 & .01 & .04 \\
\hline IL-9 & .1 & .2 \\
\hline IL-10 & .02 & .04 \\
\hline IL-12p70 & .06 & .06 \\
\hline IL-13 & .06 & .06 \\
\hline IL-15 & $<.0001$ & $<.001$ \\
\hline IL-17 & .09 & .1 \\
\hline Eotaxin & .4 & .02 \\
\hline FGF & .2 & .3 \\
\hline G-CSF & .06 & .06 \\
\hline GM-CSF & .06 & .06 \\
\hline IFN-G & .04 & .06 \\
\hline IP-10 & .4 & .5 \\
\hline MCP-1 & .1 & .2 \\
\hline MIP-1a & .008 & .008 \\
\hline MIP-1b & .07 & .1 \\
\hline PDGF & .004 & $<.002$ \\
\hline RANTES & .6 & .7 \\
\hline TNF- $\alpha$ & .007 & .006 \\
\hline VEGF & .4 & .3 \\
\hline Age $\geq 60$ & .16 & .06 \\
\hline A-ALC & .01 & .004 \\
\hline ALC-15 & $<.0004$ & $<.0001$ \\
\hline CD34 & .3 & .8 \\
\hline Disease status at transplant: complete remission & .11 & .1 \\
\hline Extra nodal sites $\geq 2$ & .46 & .8 \\
\hline LDH; abnormal & .3 & .2 \\
\hline Mono-15 & $<.001$ & $<.002$ \\
\hline NK-15 & $<.0002$ & $<.0002$ \\
\hline PS $>1$ & .24 & .81 \\
\hline Stage III/IV & .2 & .28 \\
\hline
\end{tabular}

Interleukin (IL)-1b, IL-1ra, IL-2, IL-4, IL-5, IL-6, IL-7, IL-8, IL-9, IL-10, IL-12p70, IL-13, IL-15, IL-17, Eotaxin, fibroblast growth factor (FGF), granulocyte colony-stimulating factor (G-CSF), granulocyte-macrophage colony-stimulating factor (GM-CSF), interferon-gamma (IFN-G), interferon-gamma-inducible protein 10 (IP-10), monocyte chemoattractant protein-1 (MCP-1), macrophage inflammatory proteins 1a and 1b (MIP-1a and MIP-1b), platelet-derived growth factor (PDGF), RANTES, tumor-necrosis-factor-gamma (TNF-G), vascular endothelial growth factor (VEGF), autograft absolute lymphocyte count (A-ALC), absolute lymphocyte count at day 15 post transplant (ALC-15), lactate dehydrogenase (LDH), absolute monocyte count at day 15 post transplant (Mono-15), natural killer cells at day 15 post transplant (NK-15), and performance status (PS).

3.3.1. Source of IL-15 at Day 15 Post-APHSCT (Monocytes/Macrophages). The monocytic/macrophage system has been reported as a source of IL-15. Thus, we set out to investigate that the monocytic count at day 15 (mono-15) post-APHSCT affects IL-15 levels. We identified a good correlation between IL-15 and mono- $15\left(r_{s}=0.8, P<.0001\right)$ (Figure 5). We also identified a good correlation between
NK-15 and mono-15 $\left(r_{s}=0.54, P<.0001\right)$. However, in logistic regression analysis, IL-15 and A-ALC remained statistical significant as sources of NK-15 and truncated mono-15 $(P=.1)$ (Table 6), suggesting that the mono-15 ability to affect NK-15 is mediated by the production of IL15. Mono- 15 was also associated with OS $(P<.001)$ and PFS $(P<.002)$ (Figures 6(a) and 6(b)). However, in multivariate 


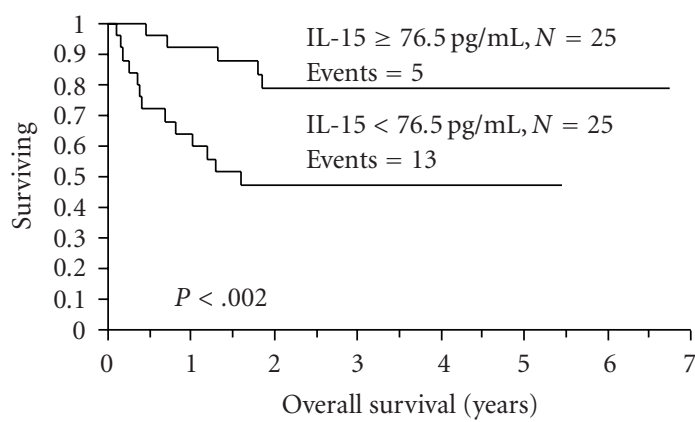

Number at risk

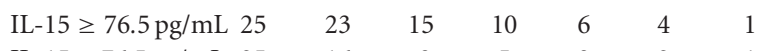

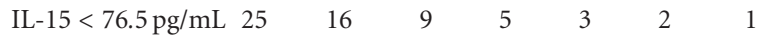

(a)

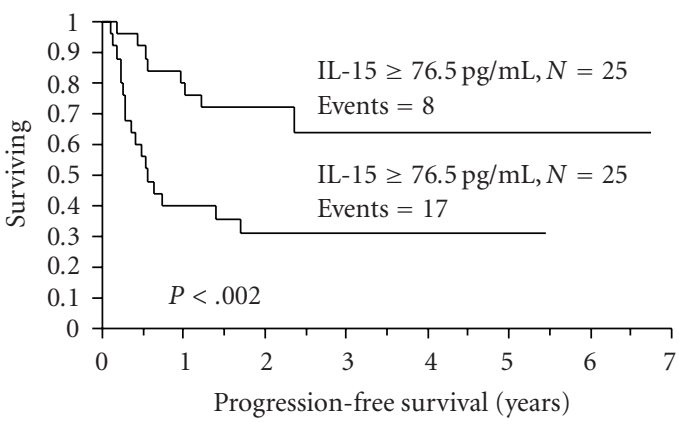

Number at risk

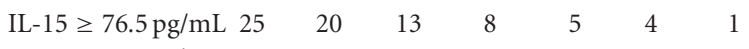

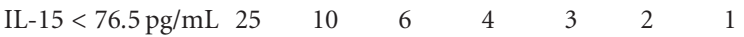

(b)

FIGURE 3: (a) Overall survival (OS) of patients with an interleukin-15 (IL-15) $\geq 76.5 \mathrm{pg} / \mathrm{mL}$ versus patients with an IL-15 $<76.5 \mathrm{pg} / \mathrm{mL}$. The median OS was not reached in the group of patients with an IL-15 $\geq 76.5 \mathrm{pg} / \mathrm{mL}$ and 19.2 months with the group of patients with an IL-15, $76.5 \mathrm{pg} / \mathrm{mL}$. The OS rates at 3 years were $79 \%$ and $47 \%$, respectively $(P<.002)$. (b) Progression-free survival (PFS) of patients with an interleukin-15 (IL-15) $\geq 76.5 \mathrm{pg} / \mathrm{mL}$ versus patients with an IL-15 $<76.5 \mathrm{pg} / \mathrm{mL}$. The median PFS was not reached in the group of patients with an IL- $15 \geq 76.5 \mathrm{pg} / \mathrm{mL}$ and 6.8 months with the group of patients with an IL-15, $76.5 \mathrm{pg} / \mathrm{mL}$. The PFS rates at 3 years were $64 \%$ and $31 \%$, respectively $(P<.002)$.

analysis, NK-15 remained the only statical prognostic factor for survival compared with mono-15 (OS, $P=$.9; PFS, $P=$ .9 ), or ALC-15 (OS, $P=.8$; PFS, $P=.2$ ) (Table 7). To assess the source of mono-15 recovery, we analyzed the number of A-mono infused and found a good correlation between Amono and mono-15 $\left(r_{s}=0.5, P<.001\right)$. In addition, we identified a positive correlation between A-mono and NK-15 $(r=0.4, P<.008)$ and between A-mono and IL-15 at day 15 post-APHSCT $(r=0.3, P<.04)$.

\section{Discussion}

ALC-15 $\geq 500$ cells $/ \mu \mathrm{L}$ is a prognostic factor for survival post-APHSCT. NK-15 is the key lymphocyte subset of ALC-15 contributing to the superior clinical outcomes that observed post-APHSCT. ALC-15 and NK-15 recovery depends on the infused A-ALC, suggesting the new concept that the autograft used to infuse stem cells in APHSCT can be used also as an adoptive immunotherapeutic maneuver to enhance immune recovery, translating into better clinical outcomes post-APHSCT. However, for an adoptive cellular therapy to be effective, it requires cellular proliferation while preserving the effector function. We have previously published that NK cells at two weeks post-APHSCT are functionally active [22]. Thus, we studied the cytokine milieu at day 15 post-APHSCT to assess its interaction with NK-15 recovery and survival post-APHSCT.

Our cytokine profile at day 15 post-APHSCT is similar to what has been previously reported in autologous stem cell transplantation. [23, 24]. However, to our knowledge this is the first study looking at the role of IL-15 on NK15 recovery and survival post-APHSCT. IL-15 was the only cytokine at day 15 post-APHSCT that was associated with survival post-transplant. IL-15 has been reported to support the homeostasis of IL-2/IL-15R $\beta$ expressing memory CD8+

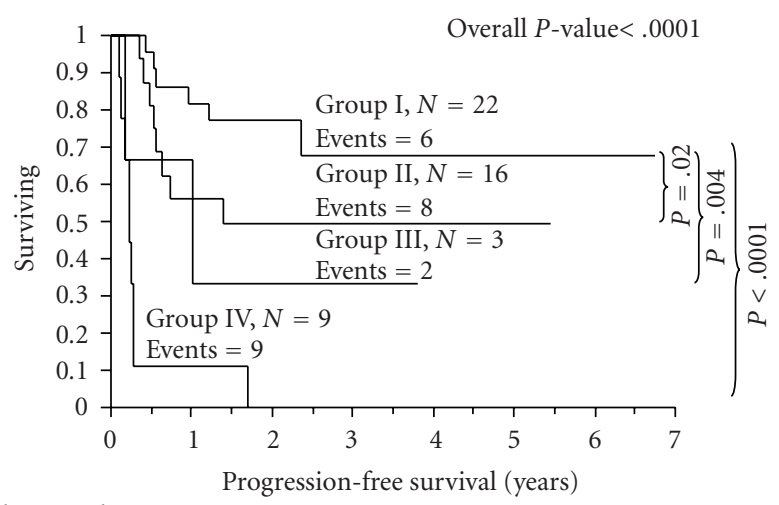

\begin{tabular}{lccccccc} 
Number at risk & \multicolumn{1}{l}{ (1) } \\
Group I & 22 & 19 & 12 & 7 & 5 & 4 & 2 \\
Group II & 16 & 9 & 6 & 4 & 3 & 2 & \\
Group III & 3 & 2 & 1 & 1 & & & \\
Group IV & 9 & 1 & & & &
\end{tabular}

Figure 4: Progression-free survival based on categorized subset analysis of NK-15 and IL-15 levels. Group I was patients with an $\mathrm{NK}-15 \geq 80$ cells $/ \mu \mathrm{L}$ and IL- $15 \geq 76.5 \mathrm{pg} / \mathrm{mL}$; group II was NK$15 \geq 80$ cells $/ \mu \mathrm{L}$ and IL- $15<76.5 \mathrm{pg} / \mathrm{mL}$; group III was NK-15 $<80$ cells $/ \mu \mathrm{L}$ and IL- $15 \geq 76.5 \mathrm{pg} / \mathrm{mL}$; group IV was NK-15 < 80 cells $/ \mu \mathrm{L}$ and IL- $15<76.5 \mathrm{pg} / \mathrm{mL}$. The 3 -year PFS rate for group I was $68 \%$; group II was $49 \%$; group III was $33 \%$; group IV was $0 \%$.

T cells and NK cells via transpresentation of IL-15 by IL$15 \mathrm{R} \alpha$ expressing cells $[25,26]$. We previously reported that NK-15 is the key lymphocyte subset of ALC-15 affecting survival post-APHSCT [13]. Since IL-15 has been associated with NK cells homeostasis and differentiation, we set out to identify if there was an association between IL-15 and NK-15 post-APHSCT. We identified a strong correlation between IL-15 and NK-15 as a continuous or dichotomized variable. Our finding is similar to what has been reported 
TABLe 5: Patients baseline characteristics based on IL-15 $\geq 76.5 \mathrm{pg} / \mathrm{mL}$ versus IL- $15<76.5 \mathrm{pg} / \mathrm{mL}$.

\begin{tabular}{|c|c|c|c|}
\hline Characteristics & IL- $15<76.5 \mathrm{pg} / \mathrm{mL}(n=25)$ & IL- $15 \geq 76.5 \mathrm{pg} / \mathrm{mL}(n=25)$ & $P$-value \\
\hline Age at transplant, years: median (range) & $62(44-73)$ & $54(23-71)$ & .02 \\
\hline Gender & & & .2 \\
\hline Female & 6 & 11 & \\
\hline Male & 19 & 14 & \\
\hline Lymphoma type & & & .7 \\
\hline DLBCL & 17 & 17 & \\
\hline Mantle cell & 5 & 5 & \\
\hline T-cell & 3 & 2 & \\
\hline Follicular & 0 & 1 & \\
\hline \multicolumn{4}{|l|}{ Prognostic factors at diagnosis } \\
\hline Extranodal disease & & & .2 \\
\hline 0 & 15 & 17 & \\
\hline 1 & 8 & 7 & \\
\hline 2 & 2 & 0 & \\
\hline LDH (U/L), median (range) & $222(150-550)$ & $200(170-1515)$ & .5 \\
\hline Performance status & & & .1 \\
\hline 0 & 12 & 19 & \\
\hline 1 & 12 & 5 & \\
\hline 2 & 1 & 1 & \\
\hline Stage & & & .3 \\
\hline I & 2 & 4 & \\
\hline II & 1 & 4 & \\
\hline III & 4 & 4 & \\
\hline IV & 18 & 13 & \\
\hline \multicolumn{4}{|l|}{ IPI score } \\
\hline Age at transplant, years & & & .1 \\
\hline$\geq 60$ & 15 & 8 & \\
\hline$<60$ & 10 & 17 & \\
\hline Extranodal sites & & & .5 \\
\hline$\geq 2$ & 2 & 0 & \\
\hline$<2$ & 23 & 25 & \\
\hline $\mathrm{LDH}(\mathrm{U} / \mathrm{L})$ & & & .3 \\
\hline Abnormal & 13 & 8 & \\
\hline Normal & 12 & 17 & \\
\hline Performance status & & & .9 \\
\hline$\geq 2$ & 1 & 1 & \\
\hline$<2$ & 24 & 24 & \\
\hline Stage & & & .2 \\
\hline $\mathrm{I} / \mathrm{II}$ & 3 & 8 & \\
\hline III/IV & 22 & 17 & \\
\hline IPI index & & & .03 \\
\hline 0 & 1 & 4 & \\
\hline 1 & 4 & 11 & \\
\hline 2 & 15 & 7 & \\
\hline 3 & 5 & 3 & \\
\hline Disease status prior to transplant & & & .5 \\
\hline $\mathrm{CR}$ & 6 & 9 & \\
\hline PR & 19 & 16 & \\
\hline
\end{tabular}


TABle 5: Continued.

\begin{tabular}{|c|c|c|c|}
\hline Characteristics & IL-15 $<76.5 \mathrm{pg} / \mathrm{mL}(n=25)$ & IL- $15 \geq 76.5 \mathrm{pg} / \mathrm{mL}(n=25)$ & $P$-value \\
\hline Infused CD34 cells $\times 10^{6} / \mathrm{kg}$; median (range) & $5.17(2.2-8.56)$ & $4.4(2.03-8.1)$ & .2 \\
\hline ALC- 15 cells/ $\mu \mathrm{L}$ : median (range) & $0.65(0.02-1.91)$ & $0.68(0.1-4.5)$ & .2 \\
\hline ALC -15 cells $/ \mu \mathrm{L}$ & & & .2 \\
\hline$\geq 500$ & 15 & 20 & \\
\hline$<500$ & 10 & 5 & \\
\hline Infused A-ALC $\times 10^{9}$ lymphocytes/kg: median (range) & $0.55(0.02-1.66)$ & $0.63(0.14-1.66)$ & .1 \\
\hline Infused A-ALC & & & .2 \\
\hline$\geq 0.5 \times 10^{9}$ lymphocytes $/ \mathrm{kg}$ & 14 & 19 & \\
\hline$<0.5 \times 10^{9}$ lymphocytes $/ \mathrm{kg}$ & 11 & 6 & \\
\hline Infused A-mono $\times 10^{9}$ monocytes $/ \mathrm{kg}:$ median (range) & $0.57(0.06-1.5)$ & $0.65(0.26-1.5)$ & .3 \\
\hline Mono- 15 cells/ $\mu \mathrm{L}:$ median (range) & $0.85(0.02-2)$ & $0.86(0.06-4.5)$ & .8 \\
\hline NK-15 cells/ $\mu \mathrm{L}:$ median (range) & $98(10-744)$ & $130(12-999)$ & .8 \\
\hline
\end{tabular}

A-ALC: autograft, absolute lymphocyte count; ALC-15: absolute lymphocyte count at day 15 post transplant; A-mono: autograft absolute monocyte count; CR: complete remission; DLBCL: diffuse large B-cell lymphoma; IPI: International prognostic index; LDH: lactate dehydrogenase; Mono-15: absolute monocyte count at day 15 post transplant; PR: partial remission; NK-15: absolute natural killer cell count at day 15 post transplant.

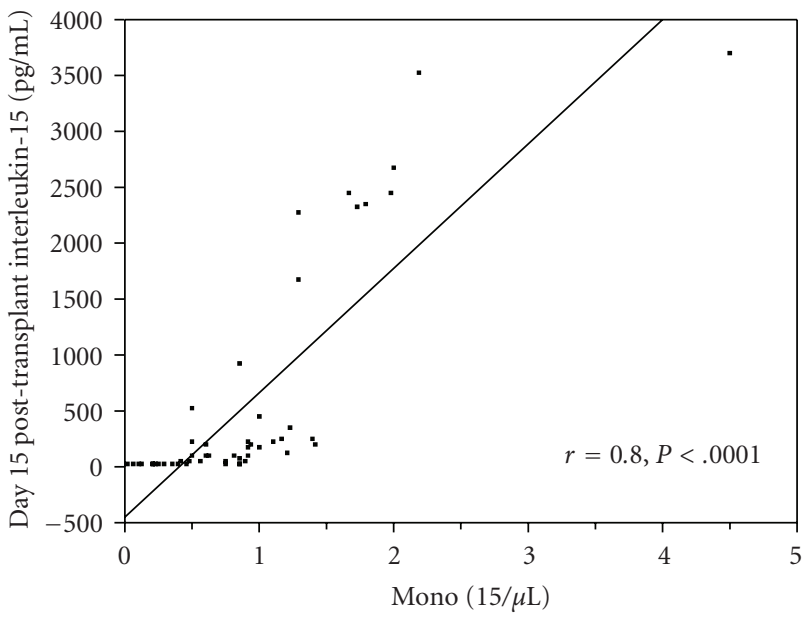

FIGURE 5: Scatterplot comparing IL-15 and mono-15 at day 15 postAPHSCT. Strong positive correlation was identified between IL-15 and mono-15 post-APHSCT (Spearman correlation rho factor, $r_{s}=$ $0.8, P<.0001)$.

in allogeneic stem cell transplantation, where faster NK cell recovery early post allogeneic stem cell transplantation is associated with elevated IL-15 levels [27]. Despite the small number of patients, patients with higher NK-15 and IL-15 levels experienced better PFS compared with patients with progressing lower NK-15 and IL-15 levels. Multivariate analysis showed that NK-15 truncated IL-15 levels, suggesting that the possibility that the survival benefit observed by IL-15 is mediated by enhanced NK cell recovery post-APHSCT. Another factor associated with NK-15 and previously reported was A-ALC. A-ALC was an independent factor affecting NK-15 recovery when compared with IL-15, suggesting that A-ALC, as an adoptive cellular therapy, provides a direct influx of immune effector cells (i.e., NK cells), while IL-15 helps to sustain the proliferation of NK cells.
TABLE 6: Logistic regression analysis of factors affecting NK-15 recovery post-APHSCT.

\begin{tabular}{lcccc}
\hline Factors & Estimate & $\begin{array}{c}\text { Standard } \\
\text { Error }\end{array}$ & $\chi^{2}$ & $P$-value \\
\hline A-ALC & 20.6 & 79.9 & 18.2 & $<.0001$ \\
$\begin{array}{l}\text { IL-15 at day 15 } \\
\text { post-APHSCT }\end{array}$ & 19.9 & 85.6 & 8.3 & $<.004$ \\
Mono-15 & 1.32 & 0.75 & 1.7 & .1 \\
\hline
\end{tabular}

A-ALC: autograft, absolute lymphocyte count; APHSCT: autologous peripheral blood hematopoietic stem cell transplantation; IL-15: interleukin-15; Mono-15: absolute monocyte count at day 15 post transplant; $\chi^{2}$ : chi square.

TABLe 7: Multivariate analysis for overall and progression-free survival.

\begin{tabular}{lccccccc}
\hline \multirow{2}{*}{ Factors } & \multicolumn{3}{c}{ Overall survival } & \multicolumn{3}{c}{ Progression-free survival } \\
& RR & $95 \%$ CI & $P$-value & RR & $95 \%$ CI & $P$-value \\
\hline ALC-15 & 0.656 & $0.128-2.657$ & .8 & 0.628 & $0.152-2.107$ & .2 \\
Mono-15 & 1.125 & $0.316-3.317$ & .9 & 1.060 & $0.374-2.637$ & .9 \\
NK-15 & 0.176 & $0.062-0.797$ & $<.006$ & 0.188 & $0.057-0.593$ & $<.002$ \\
\hline
\end{tabular}

ALC-15: absolute lymphocyte count at day 15 post transplant; Mono-15: absolute monocyte count at day 15 post transplant; and NK-15: natural killer cells at day 15 post transplant.

Due to the apparent role of IL-15 on NK-15 recovery, we set out to investigate possible sources of IL-15 at day 15 post-APHSCT. Monocytes have been implicated as a source of IL-15 [28]. Thus, we studied the monocyte recovery at day 15 (mono-15) post-APHSCT, as a surrogate marker of IL-15 production, and its correlation with IL-15 levels. We identified a strong correlation between mono15 and IL-15 at day 15 post-APHSCT. We also found an association between mono-15 and NK-15. However, a multivariate analysis showed IL-15 and not mono-15 as the factor affecting NK-15 recovery, suggesting that the effect 


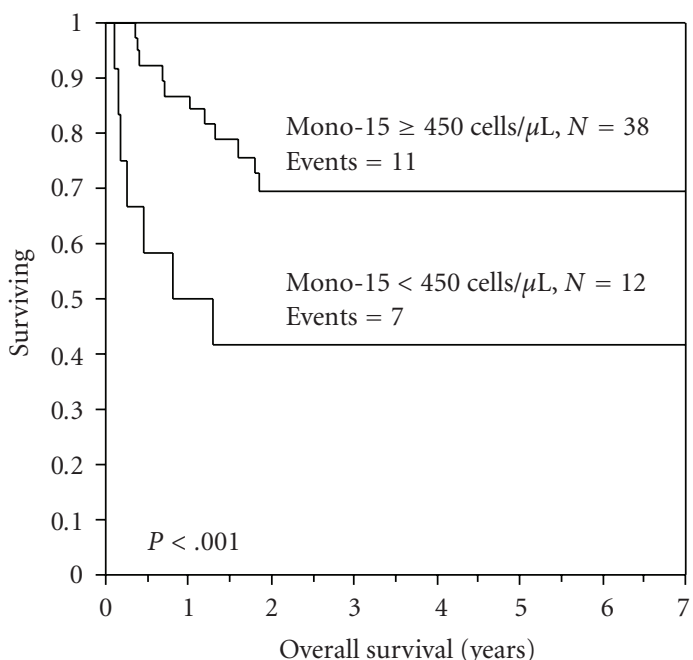

Number at risk Mono- $15 \geq 450$ cells $\mu \mathrm{L} 38$ Mono- $15<450$ cells $\mu \mathrm{L} 12$

$\begin{array}{ccccccc}33 & 19 & 10 & 5 & 3 & 2 & 1 \\ 7 & 6 & 5 & 4 & 3 & 2 & 1\end{array}$

(a)

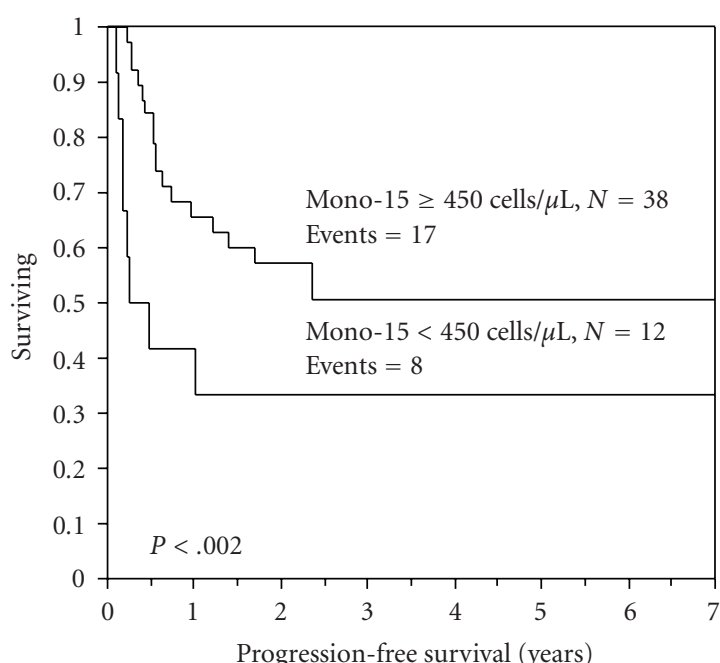

Number at risk

Mono- $15 \geq 450$ cells $/ \mu \mathrm{L} 38$

Mono- $15<450$ cells $/ \mu \mathrm{L} 12$
Progression-free survival (years)

$\begin{array}{ccccccc}26 & 15 & 7 & 5 & 4 & 2 & 1 \\ 6 & 4 & 4 & 3 & 3 & 2 & 1\end{array}$

(b)

FIGURE 6: (a) Overall survival (OS) of patients with a mono- $15 \geq 450$ cells $/ \mu \mathrm{L}$ versus patients with a mono- $15<450$ cells/ $\mu \mathrm{L}$. The median OS was not reached in the group of patients with a mono- $15 \geq 450$ cells/ $\mu \mathrm{L}$ and 12.6 months with the group of patients with a mono- 15 $<450$ cells $/ \mu \mathrm{L}$. The OS rates at 3 years were $70 \%$ and $42 \%$, respectively $(P<.001)$. (b) Progression-free survival (PFS) of patients with a mono- $15 \geq 450$ cells $/ \mu \mathrm{L}$ versus patients with a mono- $15<450$ cells $/ \mu \mathrm{L}$. The median PFS was not reached in the group of patients with a mono- $15 \geq 450$ cells $/ \mu \mathrm{L}$ and 4.5 months with the group of patients with a mono- $15<450$ cells $/ \mu \mathrm{L}$. The PFS rates at 3 years were $71 \%$ and $33 \%$, respectively $(P<.002)$.

on NK-15 recovery by mono-15 is most likely mediated by the production of IL-15 by mono-15. Another possible source of IL-15 is from dendritic cells [28]. Recently, it has been reported that the infusion of autograft dendritic cells as well as their recovery post transplant affects survival in lymphoma patients treated with APHSCT [29]. It is reasonable to hypothesize that the survival benefit from the infusion and recovery of dendritic cells post-APHSCT could also be related due to the production of IL-15 by dendritic cells activating NK cells. However, it is important to mention other factors that could affect the IL-15 levels during the peritransplant period including (1) depletion of the lymphoid populations that normally consumed circulating IL-15 due to the conditioning regimens [27], or (2) response to the inflammatory environment triggered by the conditioning regimens [30, 31].

A limitation of the study is that even though we identified prospectively a correlation between IL-15 and NK-15 leading to better survival post-APHSCT, it does not prove causation. This limitation is based on the fact that this is a prospective correlative study which might not have controlled for factors that could have affect IL-15 levels post-APHSCT such as (1) prior treatments before APHSCT and fludarabine-based regimens that could have affected A-ALC collection, ALC15 recovery (i.e., NK-15), as well as mono- 15 recovery postAPHSCT; and (2) the use of sargramostim affecting cytokine production. However, patient's baseline characteristics were overall balanced regardless if IL-15 levels were equal/above or below $76.5 \mathrm{pg} / \mathrm{mL}$. The positive correlation between pre- and
post-APHSCT IL-15 levels suggests that the pretransplant IL15 levels might help to anticipate prognosis after APHSCT. We hope that our ongoing Phase III randomized doubleblind trial assessing if higher infusion of A-ALC translates into faster immune recovery and thus better survival postAPHSCT will address the relationship between IL-15 and NK cells as ancillary immunologic studies will be performed on this trial. In this trial none of the patients will receive sargramostim post-APHSCT. The premise of this phase III study is based on the fact that we have shown that by manipulating the mononuclear cell band during the centrifugation process of the apheresis machine, we can collect higher numbers of naïve T-cells and NK cells with direct impact on immune recovery post-APHSCT [32]. In this study, patients will be randomized to collect stem cells with the standard apheresis machine settings versus the modified apheresis machine settings, aiming at collecting more immune effector cells. Similarly, the results of the current study suggest that enriching the autograft with monocytes might also have a direct impact on NK-15 recovery and survival post-APHSCT. This hypothesis will be tested in the phase III study.

Based on the results of this study it appears that NK-15 recovery (the key lymphocyte subset of ALC-15 affecting survival post-APHSCT) depends on the adoptive infusion from A-ALC and the homeostatic/proliferative effect of IL-15. Monocytes/dendritic cells appear to mediate an NK cell supportive "homeostatic environment" potentially facilitating NK cells engraftment mediated by IL15 following-APHSCT, ultimately leading to a therapeutic 


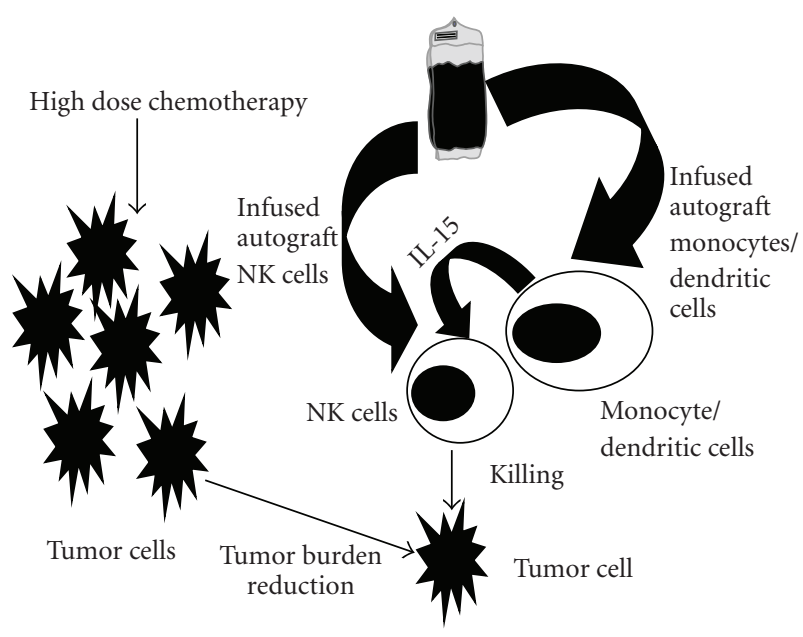

FIGURE 7: Schematic representation of autologous graft-versustumor effect (hypothesis).

autologous graft-versus-tumor effect (Figure 7). Evaluation of this hypothesis is currently underway on our Phase III study (Study ID: CDR0000577897, MAYO-MC0681).

In summary, this is the first study showing the role IL-15 on survival post-APHSCT most likely by supporting NK cells engraftment. In addition, this study also shows monocytes as possible source of IL-15, suggesting that the monocyte count can be used as a surrogate marker to assess the cytokine milieu (specifically IL-15) post-APHSCT. Further studies are warranted to understand the role of cytokines on survival post-APHSCT to develop more effective immunotherapeutic treatments in the APHSCT setting.

\section{References}

[1] L. F. Porrata, M. A. Gertz, D. J. Inwards, et al., "Early lymphocyte recovery predicts superior survival after autologous hematopoietic stem cell transplantation in multiple myeloma or non-Hodgkin lymphoma," Blood, vol. 98, no. 3, pp. 579$585,2001$.

[2] L. F. Porrata, D. J. Inwards, I. N. Micallef, S. M. Ansell, S. M. Geyer, and S. N. Markovic, "Early lymphocyte recovery post-autologous haematopoietic stem cell transplantation is associated with better survival in Hodgkin's disease," British Journal of Haematology, vol. 117, no. 3, pp. 629-633, 2002.

[3] L. F. Porrata, M. R. Litzow, A. Tefferi, et al., "Early lymphocyte recovery is a predictive factor for prolonged survival after autologous hematopoietic stem cell transplantation for acute myelogenous leukemia," Leukemia, vol. 16, no. 7, pp. 1311$1318,2002$.

[4] C. Joao, L. F. Porrata, D. J. Inwards, et al., "Early lymphocyte recovery after autologous stem cell transplantation predicts superior survival in mantle-cell lymphoma," Bone Marrow Transplantation, vol. 37, no. 9, pp. 865-871, 2006.

[5] H. Kim, H.-J. Sohn, S. Kim, J.-S. Lee, W.-K. Kim, and C. Suh, "Early lymphocyte recovery predicts longer survival after autologous peripheral blood stem cell transplantation in multiple myeloma," Bone Marrow Transplantation, vol. 37, no. 11, pp. 1037-1042, 2006.
[6] M. R. Boulassel, A. L. Herr, M. D. Deb Edwardes, et al., "Early lymphocyte recovery following autologous peripheral stem cell transplantation is associated with better survival in younger patients with lymphoproliferative disorders," Hematology, vol. 11, no. 3, pp. 165-170, 2006.

[7] H. Kim, H.-J. Sohn, S.-E. Kim, et al., "Lymphocyte recovery as a positive predictor of prolonged survival after autologous peripheral blood stem cell transplantation in T-cell nonHodgkin's lymphoma," Bone Marrow Transplantation, vol. 34, no. 1, pp. 43-49, 2004.

[8] L. N. Gordan, M. W. Sugrue, J. W. Lynch, K. D. Williams, S. A. Khan, and J. S. Moreb, "Correlation of early lymphocyte recovery and progression-free survival after autologous stemcell transplant in patients with Hodgkin's and non-Hodgkin's lymphoma," Bone Marrow Transplantation, vol. 31, no. 11, pp. 1009-1013, 2003.

[9] L. F. Porrata, M. A. Gertz, M. R. Litzow, et al., "Early lymphocyte recovery predicts superior survival after autologous hematopoietic stem cell transplantation for patients with primary systemic amyloidosis," Clinical Cancer Research, vol. 11, no. 3, pp. 1210-1218, 2005.

[10] G. Ferrandina, L. Pierelli, A. Perillo, et al., "Lymphocyte recovery in advanced ovarian cancer patients after high-dose chemotherapy and peripheral blood stem cell plus growth factor support: clinical implications," Clinical Cancer Research, vol. 9, no. 1, pp. 195-200, 2003.

[11] Y. Nieto, E. J. Shpall, I. K. McNiece, et al., "Prognostic analysis of early lymphocyte recovery in patients with advanced breast cancer receiving high-dose chemotherapy with an autologous hematopoietic progenitor cell transplant," Clinical Cancer Research, vol. 10, no. 15, pp. 5076-5086, 2004.

[12] L. F. Porrata, J. N. Ingle, M. R. Litzow, S. Geyer, and S. N. Markovic, "Prolonged survival associated with early lymphocyte recovery after autologous hematopoietic stem cell transplantation for patients with metastatic breast cancer," Bone Marrow Transplantation, vol. 28, no. 9, pp. 865-871, 2001.

[13] L. F. Porrata, D. J. Inwards, S. M. Ansell, et al., "Early lymphocyte recovery predicts superior survival after autologous stem cell transplantation in non-Hodgkin lymphoma: a prospective study," Biology of Blood and Marrow Transplantation, vol. 14, no. 7, pp. 807-816, 2008.

[14] L. F. Porrata, M. R. Lotzow, D. J. Inwards, et al., "Infused peripheral blood autograft absolute lymphocyte count correlates with day 15 absolute lymphocyte count and clinical outcome after autologous peripheral hematopoietic stem cell transplantation in non-Hodgkin's lymphoma," Bone Marrow Transplantation, vol. 33, no. 3, pp. 291-298, 2004.

[15] L. F. Porrata, M. A. Gertz, S. M. Geyer, et al., "The dose of infused lymphocytes in the autograft directly correlates with clinical outcome after autologous peripheral blood hematopoietic stem cell transplantation in multiple myeloma," Leukemia, vol. 18, no. 6, pp. 1085-1092, 2004.

[16] D. K. Hiwase, S. Hiwase, M. Bailey, G. Bollard, and A. P. Schwarer, "Higher infused lymphocyte dose predicts higher lymphocyte recovery, which in turn, predicts superior overall survival following autologous hematopoietic stem cell transplantation for multiple myeloma," Biology of Blood and Marrow Transplantation, vol. 14, no. 1, pp. 116-124, 2008.

[17] N. A. Aqui and C. H. June, "Post-transplant adoptive Tcell immunotherapy," Best Practice and Research: Clinical Haematology, vol. 21, no. 3, pp. 503-519, 2008. 
[18] R. Katipamula, L. F. Porrata, D. A. Gastineau, et al., "Apheresis instrument settings influence infused absolute lymphocyte count affecting survival following autologous peripheral hematopoietic stem cell transplantation in nonHodgkin's lymphoma: the need to optimize instrument setting and define a lymphocyte collection target," Bone Marrow Transplantation, vol. 37, no. 9, pp. 811-817, 2006.

[19] B. D. Cheson, S. J. Horning, B. Coiffier, et al., "Report of an international workshop to standardize response criteria for non-Hodgkin's lymphomas," Journal of Clinical Oncology, vol. 17, no. 4, pp. 1244-1253, 1999.

[20] E. Kaplan and P. Meier, "Nonparametric estimation from incomplete observations," Journal of the American Statistical Association, vol. 53, pp. 457-481, 1958.

[21] D. Cox, "Regression models and life tables," Journal of the Royal Statistical Society B, vol. 34, pp. 187-202, 1972.

[22] L. F. Porrata, D. J. Inwards, M. Q. Lacy, and S. N. Markovic, "Immunomodulation of early engrafted natural killer cells with interleukin-2 and interferon- $\alpha$ in autologous stem cell transplantation," Bone Marrow Transplantation, vol. 28, no. 7, pp. 673-680, 2001.

[23] G. Baiocchi, G. Scambia, P. Benedetti, et al., "Autologous stem cell transplantation: sequential production of hematopoietic cytokines underlying granulocyte recovery," Cancer Research, vol. 53, no. 6, pp. 1297-1303, 1993.

[24] T. Guillaume, M. Sekhavat, D. B. Rubinstein, O. Hamdan, P. Leblanc, and M. L. Symann, "Defective cytokine production following autologous stem cell transplantation for solid tumors and hematologic malignancies regardless of bone marrow or peripheral origin and lack of evidence for a role for interleukin-10 in delayed immune reconstitution," Cancer Research, vol. 54, no. 14, pp. 3800-3807, 1994.

[25] A. Ma, R. Koka, and P. Burkett, "Diverse functions of IL-2, IL-15, and IL-7 in lymphoid homeostasis," Annual Review of Immunology, vol. 24, pp. 657-679, 2006.

[26] W. E. Carson, T. A. Fehniger, S. Haldar, et al., "A potential role for interleukin-15 in the regulation of human natural killer cell survival," Journal of Clinical Investigation, vol. 99, no. 5, pp. 937-943, 1997.

[27] M. Boyiadzis, S. Memon, J. Carson, et al., "Up-regulation of NK cell activating receptors following allogeneic hematopoietic stem cell transplantation under a lymphodepleting reduced intensity regimen is associated with elevated IL-15 levels," Biology of Blood and Marrow Transplantation, vol. 14, no. 3, pp. 290-300, 2008.

[28] T. A. Waldmann, "The biology of interleukin-2 and interleukin-15: implications for cancer therapy and vaccine design," Nature Reviews Immunology, vol. 6, no. 8, pp. 595 601, 2006.

[29] R. Dean, P. Masci, B. Pohlman, et al., "Dendritic cells in autologous hematopoietic stem cell transplantation for diffuse large B-cell lymphoma: graft content and post transplant recovery predict survival," Bone Marrow Transplantation, vol. 36, no. 12, pp. 1049-1052, 2005.

[30] T. M. Doherty, R. A. Seder, and A. Sher, "Induction and regulation of IL-15 expression in murine macrophages," Journal of Immunology, vol. 156, no. 2, pp. 735-741, 1996.

[31] G. G. Neely, S. M. Robbins, E. K. Amankwah, et al., "Lipopolysaccharide-stimulated or granulocyte-macrophage colony-stimulating factor-stimulated monocytes rapidly express biologically active IL-15 on their cell surface independent of new protein synthesis," Journal of Immunology, vol. 167, no. 9, pp. 5011-5017, 2001.
[32] C. Joao, L. F. Porrata, E. A. Burgstaler, et al., "Immunologic autograft engineering by manipulation of apheresis machine collection settings," Biology of Blood and Marrow Transplantation, vol. 12, no. 2, supplement 1, p. 105, 2006, abstract 298. 


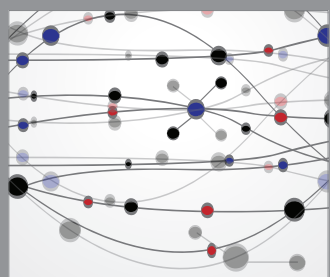

The Scientific World Journal
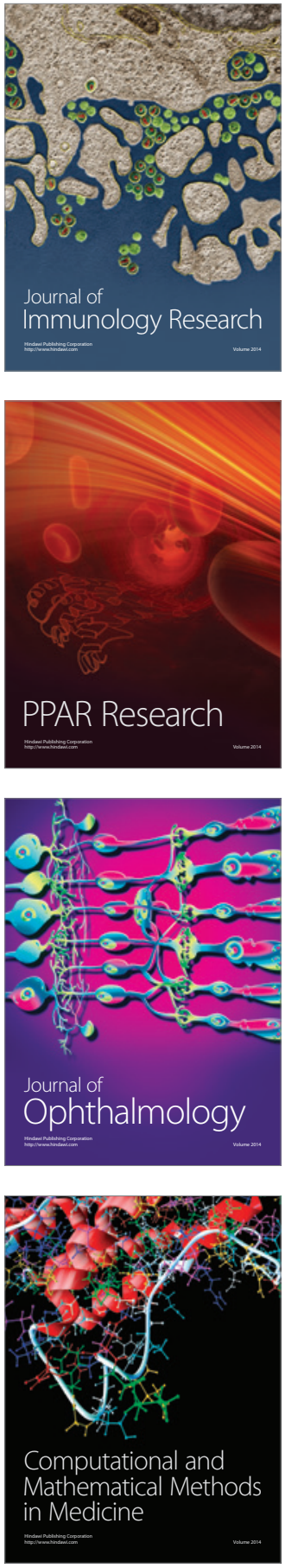

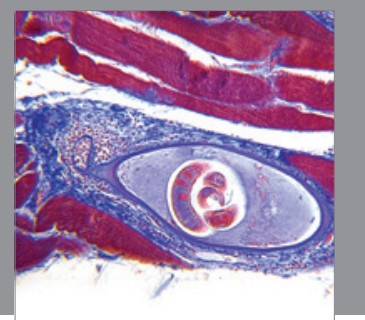

Gastroenterology

Research and Practice
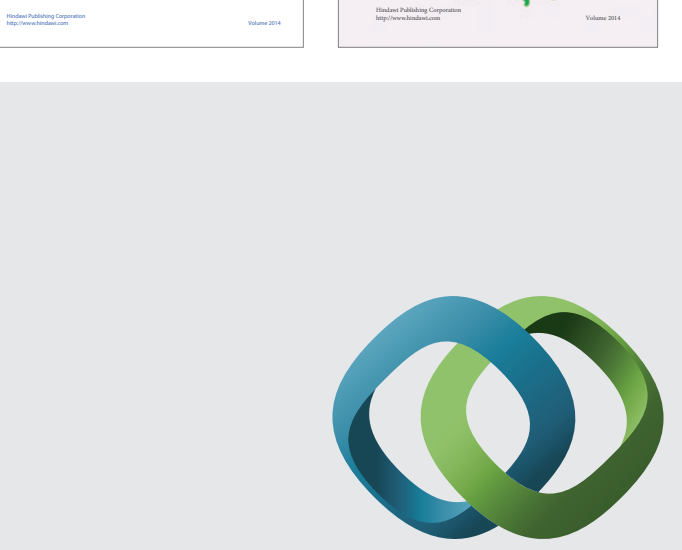

\section{Hindawi}

Submit your manuscripts at

http://www.hindawi.com
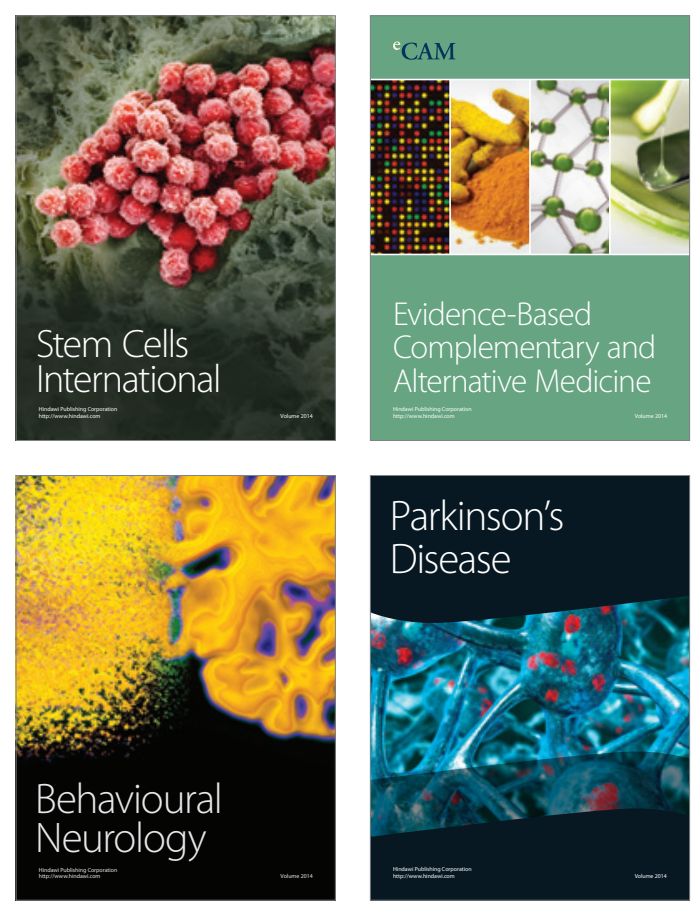

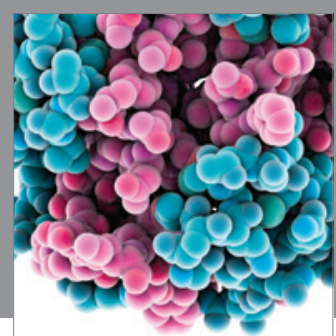

Journal of
Diabetes Research

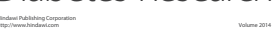

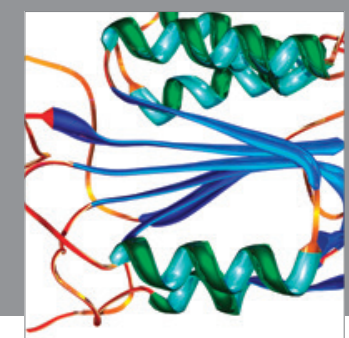

Disease Markers
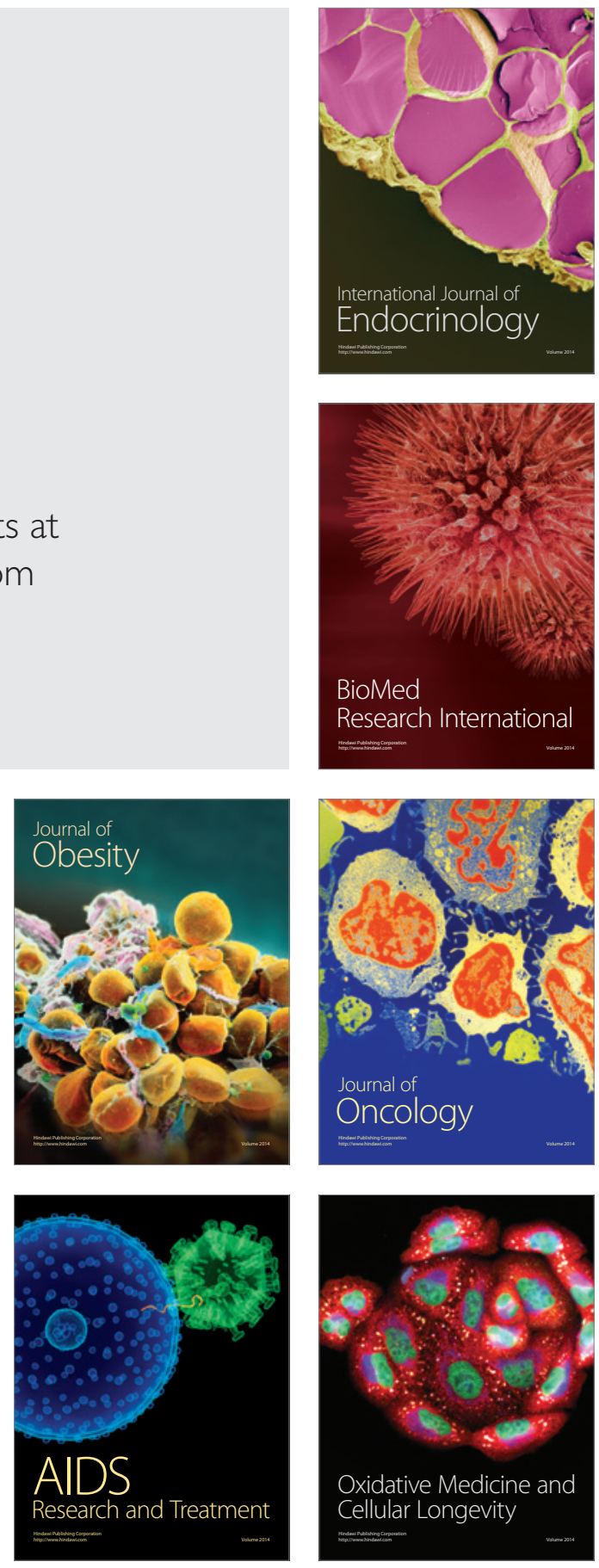